\title{
CALCULATION OF THE REACTIVITY CHANGE FROM VOIDING THE HEAVY WATER COOLANT OF THE PLUTONIUM RECYCLE TEST REACTOR
}

James Lee Maryott

June 1970

\section{AEC RESEARCH \& DEVELOPMENT REPORT}

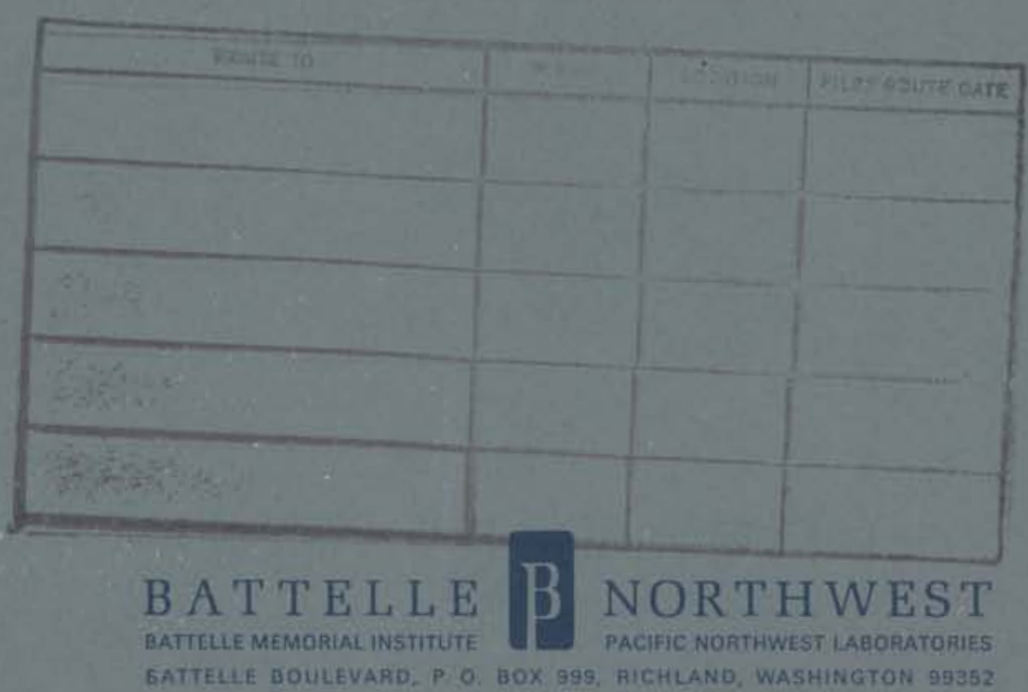




\section{LEGAL NOTICE}

This report was prepared as an account of Government sponsored work. Neither the United States, nor the Commission, ner any person acting on behalf of the Commission:

A. Makes any warranty or representation, expressed or implied, with respect to the accuracy, somplefeness, or usefulness of the information contoined in this report, or that the use of any information, apparatus, method, or process disclosed in this report may not infringe privately owned rights; or

B. Assumes any liabilities with respect to the use of, or for damages resulting from the use of any information, apparatus, method, or process disclosed in this report.

As used in the above, "person acting on behalf of the Commissian" includes any employee or contractor of the Commission, or employee of such contractor, to the extent that such employee or contractor of the Commissian, or employee of such contractor prepares, disseminates, or provides access to. any information pursuant to his employment or contract with the Commission, or his employment with such contractor.

\section{PACIFIC NORTHWEST LABORATORY \\ RICHLAND, WASHINGTON \\ operated by \\ BATTELLE MEMORIAL INSTITUTE}

for the

UNITED STATES ATOMIC ENERGY COMMISSION UNDER CONTRACT AT(45-1)-1830 
BNWL -1352

UC- 80 , Reactor

Technology

\author{
Calculation of the Reactivity Change \\ from Voiding the Heavy Water \\ Coolant of the Plutonium Recycle \\ Test Reactor* \\ by \\ James Lee Maryott \\ Reactor Physics Department \\ Physics and Engineering Division
}

June 1970

* Submitted to Oregon State University in partial fulfillment of the requirements for the degree of Master of Science in Nuclear Engineering

BATTELLE MEMORIAL INSTITUTE

PACIFIC NORTHWEST LABORATORIES

RICHLAND, WASHINGTON 99352 


\title{
Calculation of the Reactivity Change from Voiding the Heavy Water Coolant of the Plutonium Recycle Test Reactor \\ James Lee Maryott
}

\begin{abstract}
$\underline{\text { ABSTRACT }}$
A method is developed for calculating the reactivity worth of the heavy water coolant of the Plutonium Recycle Test Reactor (PRTR). The coolant reactivity worth is determined by calculating the effective multiplication constant of the reactor core with and without the coolant in given process tubes. The calculational method includes a method for calculating the resonance integrals for PRTR circular 19-rod cluster fuel elements based on experimental resonance integral data for single $\mathrm{UO}_{2}$ fuel rods and hexagonal 19 -rod clusters of $\mathrm{UO}_{2}$ fuel rods.

The calculational method is evaluated by comparing the theoretical results with experimental coolant reactivity measurements previously obtained at the PRTR. The accuracy of the calculational method is shown to be within the experimental accuracy of the cross section data by calculating the reactivity change produced by the change in each individual multigroup cross section.
\end{abstract}


TABLE OF CONTENTS

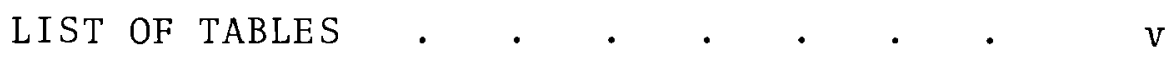

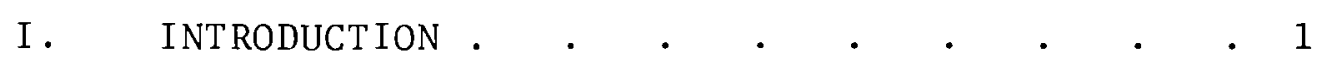

I . EXPERIMENTAL COOLANT REACTIVITY WORTH DATA • 3

Description of the PRTR Core . . . . 3

Reactivity Worth Measurements . . . 3

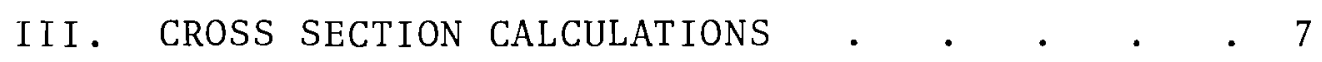

Thermal Cross Sections . . . . . 7

Resonance Integrals for Uranium-238 . . 14

Resonance Integrals for Uranium-235

and Plutonium Isotopes $\quad \cdot \quad \cdot \quad \cdot \quad \cdot \quad \cdot 19$

Epithermal and Fast Cross Sections • . 24

IV. COOLANT REACTIVITY WORTH CALCULATIONS • 25

V. MODERATOR LEVEL COEFFICIENT CALCULATIONS • • 28

VI. COMPARISON OF MEASURED AND CALCULATED
COOLANT REACTIVITY WORTHS . • • . . $\quad$ • 30

VII. SUMMARY AND CONCLUSIONS • • • • • • • 34

BIBLIOGRAPHY • • • • • • • • • 37

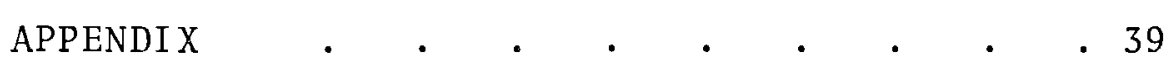

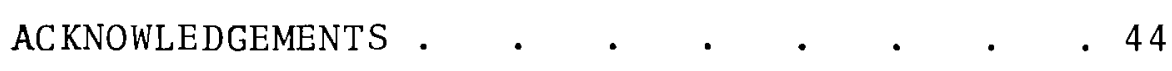




\section{LIST OF TABLES}

I

Measured Critical Moderator Level

Differences

Cylindrical Core Regions

II Fuel and Cel1 Dimensions 11

IV Fuel Density and Isotopic Compositions 12

V

Cel1 Average Few Group Parameters

VI Measured and Calculated Uranium-238

Resonance Integrals

VII Calculated Mean Cord Lengths ( $\bar{l})$ and Resonance Integrals (RI)

VIII Calculated Coolant Reactivity Worths

IX

Measured and Calculated Coolant Reactivity Worths

$\mathrm{X}$

Calculated Contributions to the Coolant Reactivity Worth from Changes in Each Cross Section 


\section{Calculation of the Reactivity Change from Voiding the Heavy Water Coolant of the Plutonium Recycle \\ Test Reactor}

\section{INTRODUCTION}

One important parameter of a water-cooled power reactor from a nuclear safety standpoint is the reactivity worth of the coolant. This parameter is important because under certain accident conditions, such as flow blockage, rapid steam formation may expel the coolant from a fuel element channel in a very short period of time.

Because of the need to predict the reactivity worth of the coolant in advance and because of the reactor outage time required to make experimental coolant reactivity worth measurements, it is desirable to be able to calculate the reactivity worth of the coolant using analytical methods.

In this work a method is developed and evaluated for calculating the reactivity worth of the coolant of the Plutonium Recycle Test Reactor (PRTR). The calculational method is evaluated by comparing the theoretical results with experimental coolant reactivity measurements previously obtained at the PRTR.

The reactivity worth of the coolant is calculated by performing diffusion theory calculations of the effective multiplication constant of the reactor core 
with and without the coolant in given process tubes. Special attention is given to developing a method for calculating the geometry-dependent resonance integrals for the PRTR fuel elements. 
II. EXPERIMENTAL COOLANT REACTIVITY WORTH DATA

Description of the PRTR Core

The PRTR is a heavy water moderated and cooled, vertical tube type reactor. The unpressurized heavy water moderator is contained in an aluminum calandria. Passing vertically through the calandria are 85 Zircaloy- 2 process tubes, containing the fuel elements which are cooled with pressurized heavy water. The process tubes are arranged on an eight inch hexagonal 1 attice.

The primary mode of reactor control is by varying the height of the moderator (moderator level) in the calandria. The calandria can contain up to 18 shim assemblies for gross adjustment of the core reactivity. The standard PRTR fuel element is a 19-rod cluster of Zircaloy-2 clad urania $\left(\mathrm{UO}_{2}\right)$ or urania-plutonia $\left(\mathrm{UO}_{2}-\mathrm{PuO}_{2}\right.$ ) fuel. Additional information on the PRTR is given in the Final Safeguards Analysis (17).

Reactivity Worth Measurements

Experimental coolant reactivity worth data have previously been measured at the PRTR. This establishes a basis of comparison with the results of the calculational method. The experimental coolant reactivity worth measurements that are used in this work were made 
by R. I. Smith (14) at the PRTR in June 1964. The reactor core configuration at the time of the experimental measurements is shown on Figure 1. A11 fue 1 elements are 19-rod clusters with a fuel length of $223.5 \mathrm{~cm}$ ( 88 inches). The top of the fuel elements are at a moderator level of $248.90 \mathrm{~cm}$ (98 inches). Experimental measurements were made of the reactivity worth of the coolant in: (a.) two process tubes containing unirradiated $\mathrm{UO}_{2}$ fuel, (b.) three process tubes containing unirradiated $\mathrm{UO}_{2}-0.48 \mathrm{wt} \% \mathrm{PuO}_{2}$ fue 1 , and (c.) three process tubes containing unirradiated $\mathrm{UO}_{2}-1.0$ wt: $\mathrm{PuO}_{2}$ fue 1 .

The reactivity worth of the coolant was measured in terms of the difference in the critical moderator leve1 with coolant and without coolant in the process tubes. 1 The critical moderator level was measured by making inverse multiplication plots of the neutron flux as a function of the moderator level.

The critica 1 moderator 1 eve 1 with a11 process tubes containing coolant was measured to be $250.50 \mathrm{~cm}$. The measured differences in the critical moderator levels with the coolant removed from the process tubes

1. Measurement of the reactivity worth of the coolant by making period measurements is usually not possib1e for a heavy water moderated reactor containing irradiated fue 1 because the $(\gamma, n)$ flux causes an excessive temperature increase in the uncooled fue 1. 
5
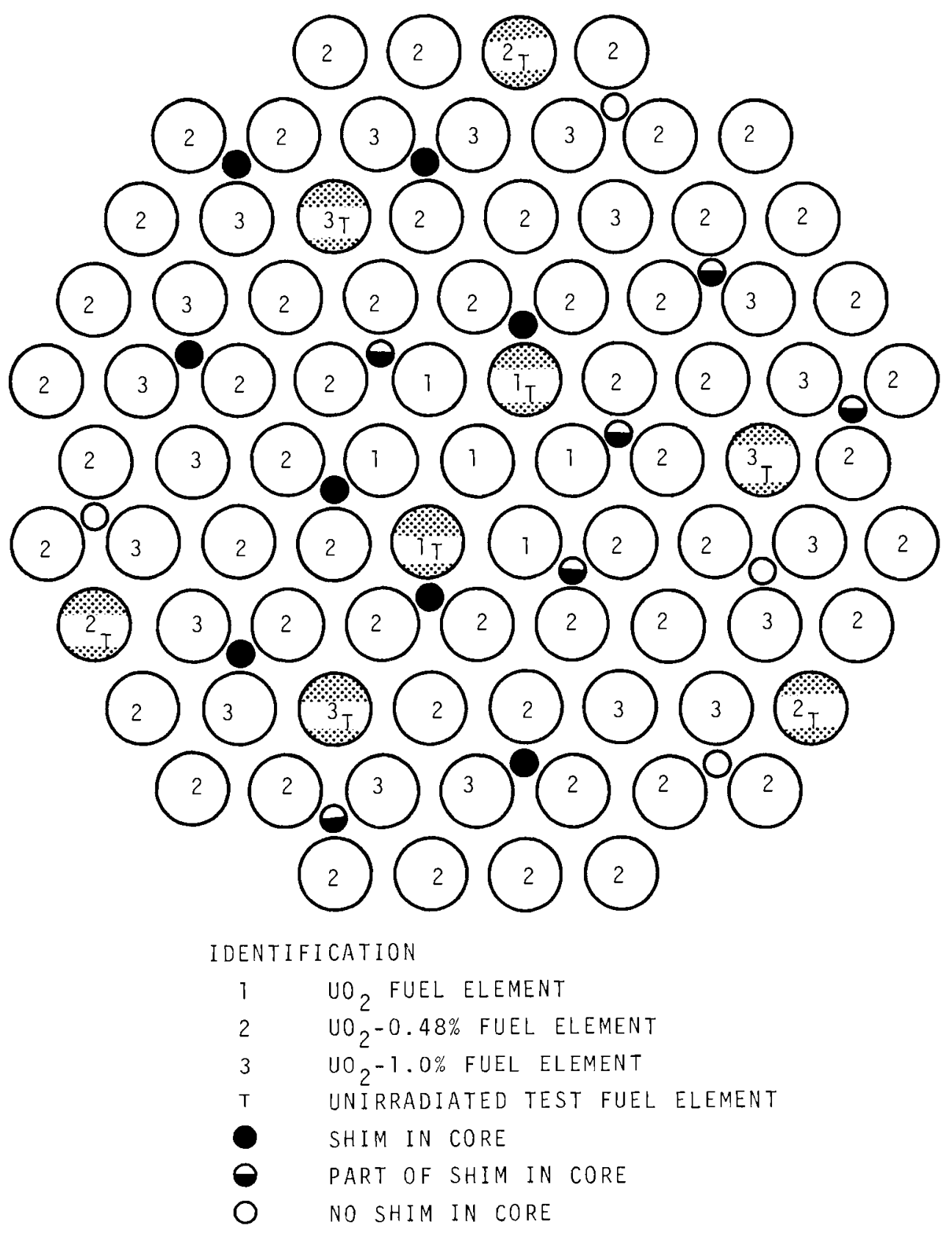

Figure 1. Reactor Core Configuration 
containing the unirradiated test fuel elements are

listed in Table I. The possible errors listed in

Table I are the standard deviations of the measurements.

TABLE I. MEASURED CRITICAL MODERATOR LEVEL DIFFERENCES

Number of Moderator Level Change Fuel Type Fue1 Elements from Removing Coolant, cm

$\begin{array}{llr}\mathrm{UO}_{2} & 2 & -0.38 \pm 0.04 \\ \mathrm{UO}_{2}-0.48 \% \mathrm{PuO}_{2} & 3 & +0.49 \pm 0.06 \\ \mathrm{UO}_{2}-1.0 \% \mathrm{PuO}_{2} & 3 & +0.09 \pm 0.05\end{array}$

As shown in Table I the critical moderator level decreased when the coolant was removed from the $\mathrm{UO}_{2}$ fuel elements, increased when the coolant was removed from the $\mathrm{UO}_{2}-0.48 \% \mathrm{PuO}_{2}$ fuel elements, and changed very little (slight increase) when the coolant was removed from the $\mathrm{UO}_{2}-1.0 \% \mathrm{PuO}_{2}$ fuel elements. The small change in the critical moderator level for the $\mathrm{UO}_{2}-1.0 \% \mathrm{PuO}_{2}$ fuel was verified with two measurements. 


\section{CROSS SECTION CALCULATIONS}

The reactivity worth of the coolant is calculated by making a diffusion theory calculation of the reactor multiplication constant with coolant and without coolant in given process tubes. For the diffusion theory calculations, the reactor core at the time of the experimental coolant reactivity worth measurements (see Figure 1 ) is converted into the 17 cylindrical regions listed in Table II. The average few-group cross sections required for the diffusion theory calculations are calculated for each of these cylindrical regions from available nuclear cross section and resonance integral data.

\section{Thermal Cross Sections}

The spectrum and volume averaged thermal cross sections for the fueled regions of the core are calculated with the computer code THERMOS $(7,18)$ The integral transport equation is solved by the THERMOS code to determine the thermal neutron spectrum as a function of position in cylindrical geometry.

The neutron energy range for the THERMOS calculations is from 0 to $0.683 \mathrm{ev}$. The basic cross section data is from the BNW Master Library (16). 
TABLE II. CYLINDRICAL CORE REGIONS

\begin{tabular}{|c|c|c|c|c|c|c|}
\hline Region & $\begin{array}{c}\text { Number } \\
\text { of Fue } 1 \\
\text { Elements } \\
\text { in } \\
\text { Region } \\
\end{array}$ & $\begin{array}{c}\text { Type of } \\
\text { Fue } 1 \\
\text { in Region }\end{array}$ & $\begin{array}{c}\text { Outer } \\
\text { Radius } \\
\text { of } \\
\text { Region, } \\
\mathrm{cm} \\
\end{array}$ & $\begin{array}{l}\text { Average } \\
\text { Exposure } \\
\text { of Fue1 } \\
\text { in } \\
\text { Region, } \\
\text { MWd/MTM } \\
\end{array}$ & & $\begin{array}{l}\text { ims } \\
\text { er } \\
\text { gion }\end{array}$ \\
\hline 1 & 1 & $\mathrm{UO}_{2}$ & 10.67 & 4,600 & 0 & \\
\hline 2 & 2 & $\mathrm{UO}_{2}$ & 18.48 & 4,600 & & $1 / 2$ \\
\hline 3 & 2 & $\mathrm{UO}_{2}$ & 23.85 & 0 & & $2 / 3$ \\
\hline 4 & 2 & $\mathrm{UO}_{2}$ & 28.23 & 4,600 & & $1 / 3$ \\
\hline 5 & 12 & $\mathrm{UO}_{2}-0.48 \% \mathrm{PuO}_{2}$ & 46.50 & 5,000 & 3 & \\
\hline 6 & 12 & $\mathrm{UO}_{2}-0.48 \% \quad \mathrm{PuO}_{2}$ & 59.40 & 5,000 & 1 & $1 / 2$ \\
\hline 7 & 2 & $\mathrm{UO}_{2}-1.0 \% \mathrm{PuO}_{2}$ & 61.29 & 1,500 & 0 & \\
\hline 8 & 3 & $\mathrm{UO}_{2}-1.0 \% \mathrm{PuO}_{2}$ & 64.01 & 0 & 0 & \\
\hline 9 & 7 & $\mathrm{UO}_{2}-1.0 \% \mathrm{PuO}_{2}$ & 69.96 & 1,500 & 1 & $1 / 2$ \\
\hline 10 & 10 & $\mathrm{UO}_{2}-1.0 \% \mathrm{PuO}_{2}$ & 77.67 & 1,500 & 1 & $5 / 6$ \\
\hline 11 & 8 & $\mathrm{UO}_{2}-0.48 \% \mathrm{PuO}_{2}$ & 83.33 & 3,200 & 1 & \\
\hline 12 & 4 & $\mathrm{UO}_{2}-0.48 \% \mathrm{PuO}_{2}$ & 86.01 & 3,200 & 0 & \\
\hline 13 & 3 & $\mathrm{UO}_{2}-0.48 \% \mathrm{PuO}_{2}$ & 87.97 & 0 & 0 & \\
\hline 14 & 17 & $\mathrm{UO}_{2}-0.48 \% \mathrm{PuO}_{2}$ & 98.36 & 3,200 & & $2 / 3$ \\
\hline 15 & - & Moderator $-\mathrm{D}_{2} \mathrm{O}$ & 106.00 & - & & - \\
\hline 16 & - & $\mathrm{Ca} 1$ anderia-A1 & 106.81 & - & & - \\
\hline 17 & - & $\operatorname{Reflector}-\mathrm{D}_{2} \mathrm{O}$ & 166.20 & - & & - \\
\hline
\end{tabular}

For the THERMOS calculations, the PRTR elementary hexagonal lattice cell is converted to a cylindrical 
ce11 of the same area, and the 19-rod-cluster fuel element is converted to the three fuel regions shown in Figure 2. In converting the PRTR 19-rod-cluster to a center fuel rod surrounded by two rings of fuel, the coolant areas inside the center line radius $r_{b}$, the coolant areas between the radii $r_{b}$ and $r_{c}$, and the coolant outside the radius $\mathrm{r}_{\mathrm{c}}$ are conserved. The cladding is homogenized with the fuel, and the helium gas gap between the process tube and the shroud tube is homogenized with the shroud tube to reduce the number of ce11 regions.

The shim rods adjacent to the two unirradiated $\mathrm{UO}_{2}$ test fuel elements are homogenized with part of the moderator as shown on Figure 2. No shims are adjacent to the unirradiated $\mathrm{UO}_{2}-0.48 \% \mathrm{PuO}_{2}$ and $\mathrm{UO}_{2}-1.0 \%$ $\mathrm{PuO}_{2}$ test fuel elements.

The dimensions of the radii shown on Figure 2 for the unirradiated test fuel elements used in the experimental coolant worth measurements are listed in Table III.

The isotopic compositions and the density of the unirradiated test fuel elements are listed in Table IV.

The isotopic composition of the primary coolant at the time of the coolant worth measurements was 97.25 molecular percent $\mathrm{D}_{2} \mathrm{O}$ and 2.75 molecular percent 


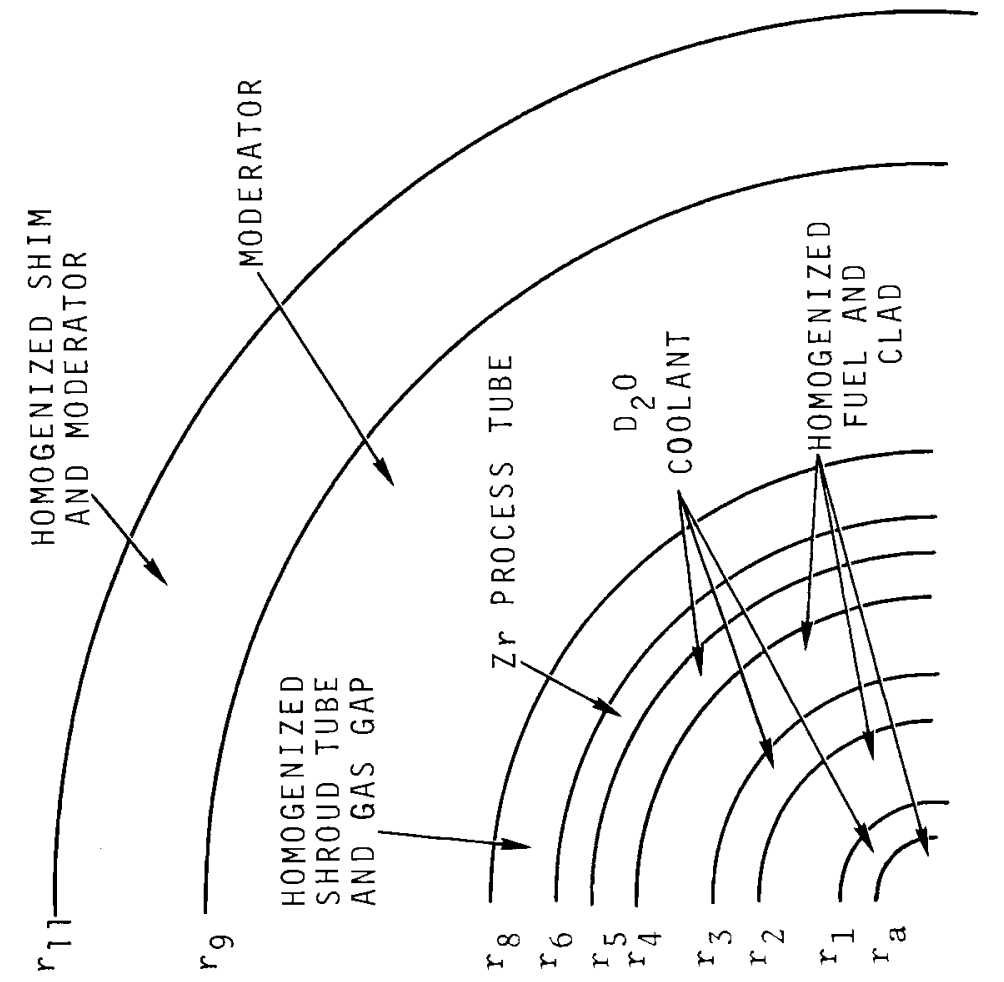

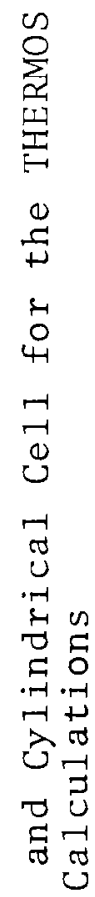

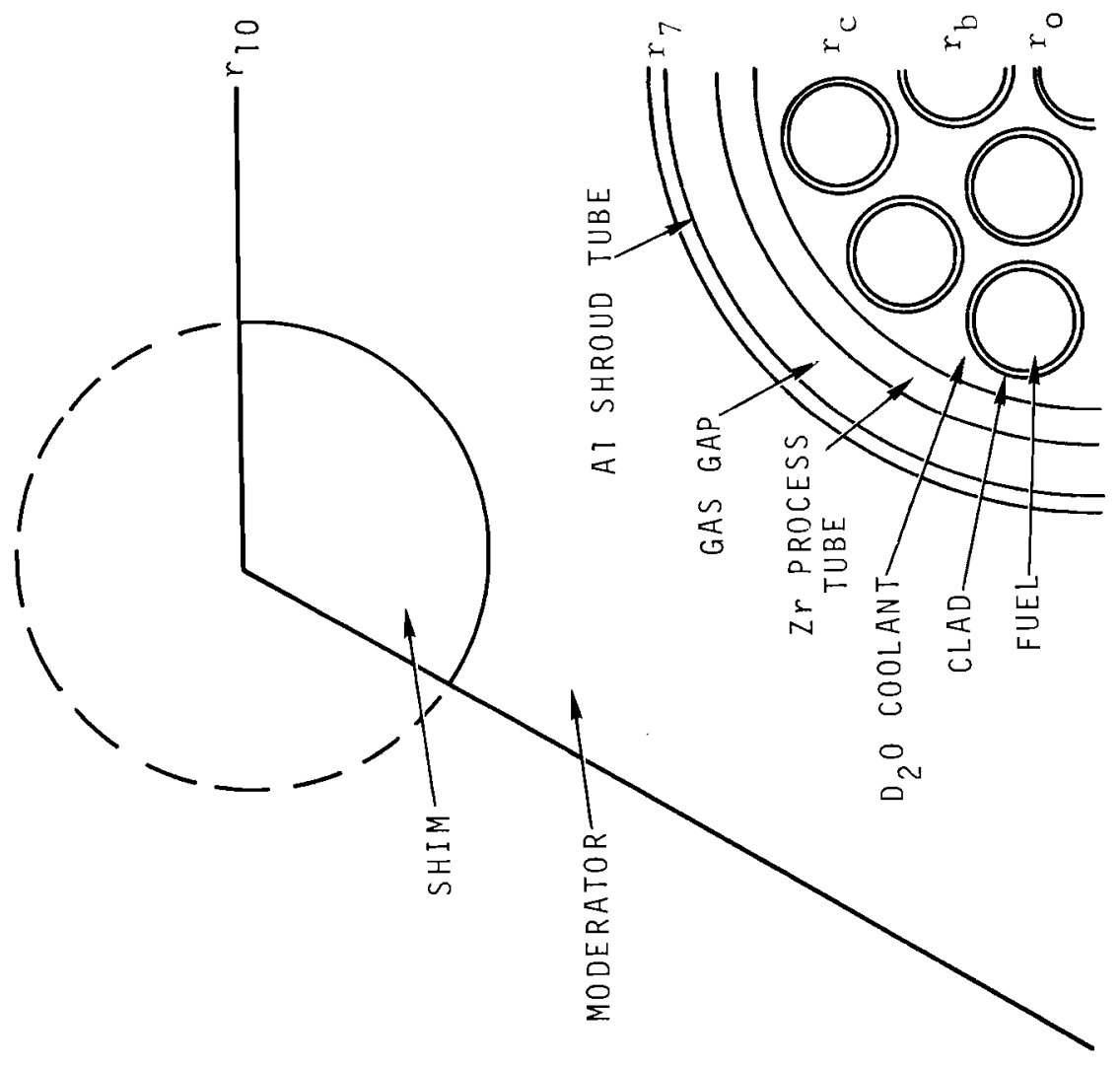

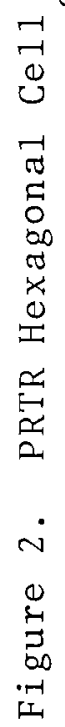


TABLE III. FUEL AND CELL DIMENSIONS

\begin{tabular}{|c|c|c|}
\hline \begin{tabular}{l}
\multicolumn{2}{c}{ Radii } \\
(Shown on \\
Figure 2) \\
\end{tabular} & $\begin{array}{c}\text { Dimensions of } \\
\mathrm{UO} 2 \text { fue } 1, \\
\mathrm{~cm}\end{array}$ & $\begin{array}{l}\text { Dimensions of } \\
\mathrm{UO}_{2}-0.48 \% \mathrm{PuO}_{2} \\
\text { and } \\
\mathrm{UO}_{2}-1.0 \% \mathrm{PuO}_{2} \\
\text { Fue } 1, \mathrm{~cm} \\
\end{array}$ \\
\hline $\mathrm{r}_{0}$ & 0.6350 & 0.6443 \\
\hline $\mathrm{r}_{\mathrm{a}}$ & 0.7137 & 0.7268 \\
\hline $\mathrm{r}_{\mathrm{b}}$ & 1.632 & 1.637 \\
\hline $\mathrm{r}_{\mathrm{e}}$ & 3.155 & 3.162 \\
\hline$r_{1}$ & 1.133 & 1.116 \\
\hline $\mathrm{r}_{2}$ & 2.083 & 2.101 \\
\hline$r_{3}$ & 2.654 & 2.643 \\
\hline$r_{4}$ & 3.627 & 3.650 \\
\hline $\mathrm{r}_{5}$ & 4.13 & 4.13 \\
\hline$r_{6}$ & 4.52 & 4.52 \\
\hline$r_{7}$ & 5.25 & 5.25 \\
\hline$r_{8}$ & 5.40 & 5.40 \\
\hline$r_{9}$ & 8.83 & - \\
\hline $\mathrm{r}_{10}$ & 10.16 & 10.16 \\
\hline$r_{11}$ & 10.67 & 10.67 \\
\hline
\end{tabular}

$\mathrm{H}_{2} \mathrm{O}$. The isotopic composition of the moderator was 99.7 molecular percent $\mathrm{D}_{2} \mathrm{O}$ and 0.3 molecular percent $\mathrm{H}_{2} \mathrm{O}$.

The thermal ce11-averaged absorption and fission cross sections calculated by THERMOS for the three kinds of unirradiated test fuel elements are listed on Table V, along with the other cell-averaged few group parameters. 
TABLE IV. FUEL DENSITY AND ISOTOPIC COMPOSITIONS

$$
\underline{\mathrm{UO}}_{2} \text { Fue } 1 \text { r } \begin{array}{r}
\mathrm{UO}_{2}-0.48 \% \\
\text { Fue1 }
\end{array}
$$

Fue1 Density, $\mathrm{gm} / \mathrm{cm}^{3}$

9.42

9.76

9.69

Weight Fraction of $239 \mathrm{Pu}$ in $\mathrm{Pu}$

0.857

0.909

Weight Fraction of $240 \mathrm{Pu}$ in $\mathrm{Pu}$

0.13

0.083

Weight Fraction of $241_{\mathrm{Pu}}$ in $\mathrm{Pu}$

0.013

0.008

Uranium

Natura1

Natura1

Natura 1

The isotopic compositions of the irradiated fue 1 elements are obtained from burnup calculations previously performed at the PRTR (13). The cel1-averaged cross sections calculated for the irradiated fuel elements are similar to the cross sections for the unirradiated test fuel elements that are listed in Table $\mathrm{V}$.

The thermal diffusion coefficients for all regions and the thermal absorption cross sections for the nonfuel regions are calculated with the nondimensional computer code TEMPEST (12). The Wigner-Wilkins light mass moderator equation is solved with the TEMPEST code to determine the thermal neutron flux spectrum. The energy-dependent cross sections are then averaged over the calculated thermal neutron spectrum to obtain average thermal parameters for the diffusion theory calculations. 


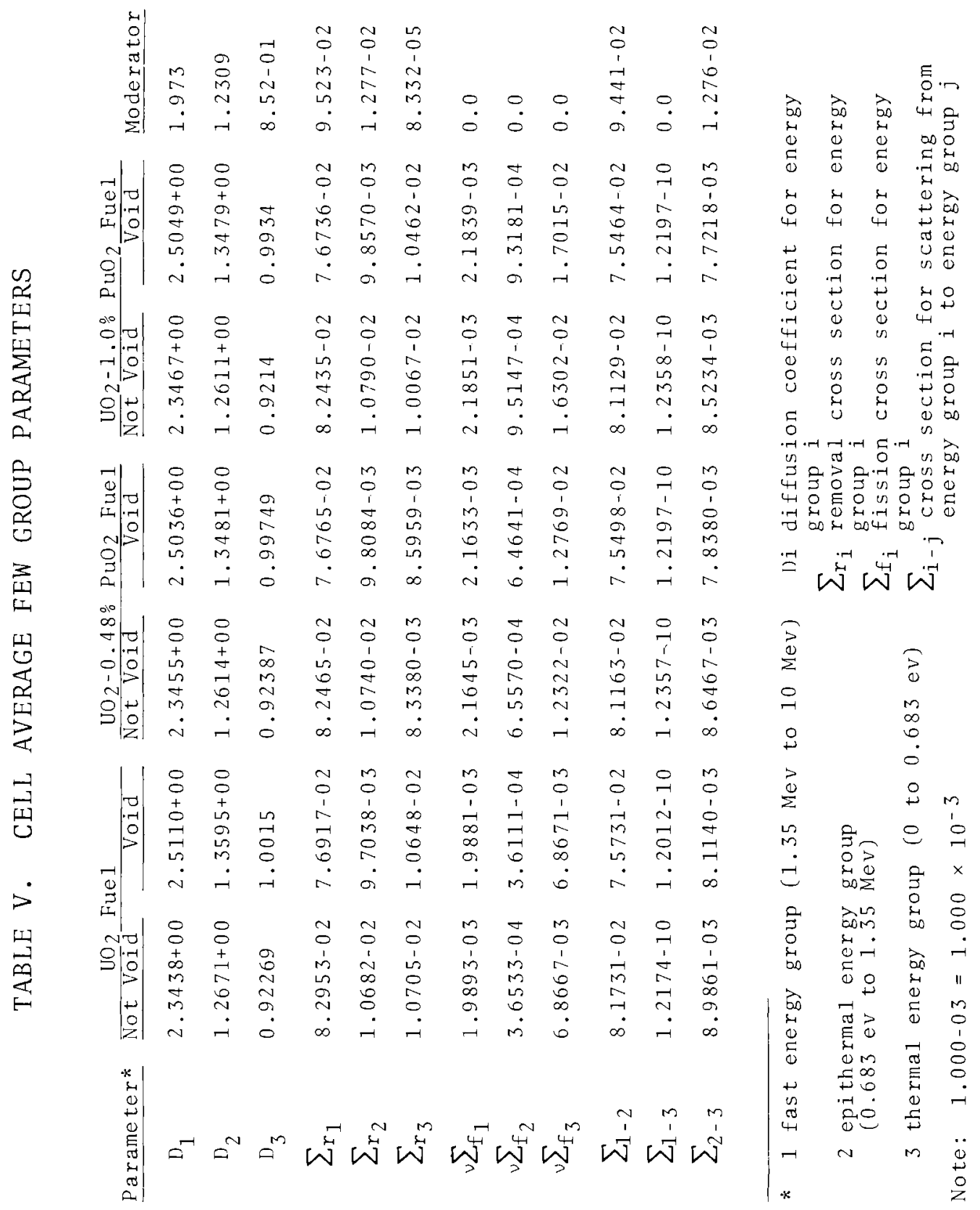


The thermal diffusion coefficients and the thermal absorption cross sections for the moderator are 1 isted in Table $\mathrm{V}$.

\section{Resonance Integra1s for Uranium-238}

The uranium-238 resonance integrals for single $\mathrm{UO}_{2}$ fuel rods and some clusters of $\mathrm{UO}_{2}$ fuel rods have been experimentally measured using activation techniques. Hellstrand $(5,6)$ found that the measured resonance integral data for $U_{2}$ fuel rods fits the equation

$$
R I=4.15+26.6 \sqrt{S / M}
$$

where $R I$ is the resonance integral of uranium-238 in barns excluding $1 / v$ capture, $S$ is the surface area of . the fuel per unit length in $\mathrm{cm}^{2} / \mathrm{cm}$, and $\mathrm{M}$ is the mass of the $\mathrm{UO}_{2}$ fuel per unit length in $\mathrm{grams} / \mathrm{cm}$.

Carlvik and Pershagen, as cited by He1lstrand developed a method based on the experimental data of He11strand to calculate an effective surface area for hexagonal clusters. The uranium-238 resonance integrals for hexagonal clusters could then be calculated from Equation (3.1). Later, Pershagen (11) showed that the calculational methods developed by Carlvik and Pershagen did not adequately calculate the resonance integrals that were measured by Bernander and Jirlow as cited by Pershagen (11). The discrepancy occurred for hexagonal 
clusters with water-to-fuel ratios larger than the water-to-fuel ratio used in the resonance integral measurements of Hellstrand.

In this work a different method is developed for calculating the effective surfaces of clusters. These effective surfaces can be used to calculate the resonance integrals of PRTR-type circular clusters as we11 as hexagonal clusters. Diagrams of the circular and hexagonal 19-rod clusters are shown on Figure 3.

For calculating the effective surface of a fue 1 element cluster with no coolant between the fuel rods, the cluster is assumed to be a low density fuel rod with the same outer surface as the cluster. The effective surface ( $S_{\text {eff }}$ ) used in Equation (3.1) for calculating the resonance integral of a cluster with no coolant between the fuel rods is

$$
S_{\text {eff }}=1.08 S_{r b}
$$

where $S_{r b}$ is the surface that would be formed if a rubber band were stretched around the cluster with no cladding on the fuel rods (rubber band surface). The equation for calculating the rubber band surface for either the circular 19-rod cluster or the hexagonal $19-$ rod cluster is

$$
\mathrm{S}_{\mathrm{rb}}=12\left[\ell+30 \pi \mathrm{r}_{\mathrm{o}} / 180\right]
$$

where $\ell$ is the distance between the centers of the fuel rods, and $r_{0}$ is the radius of the bare fuel rods. 


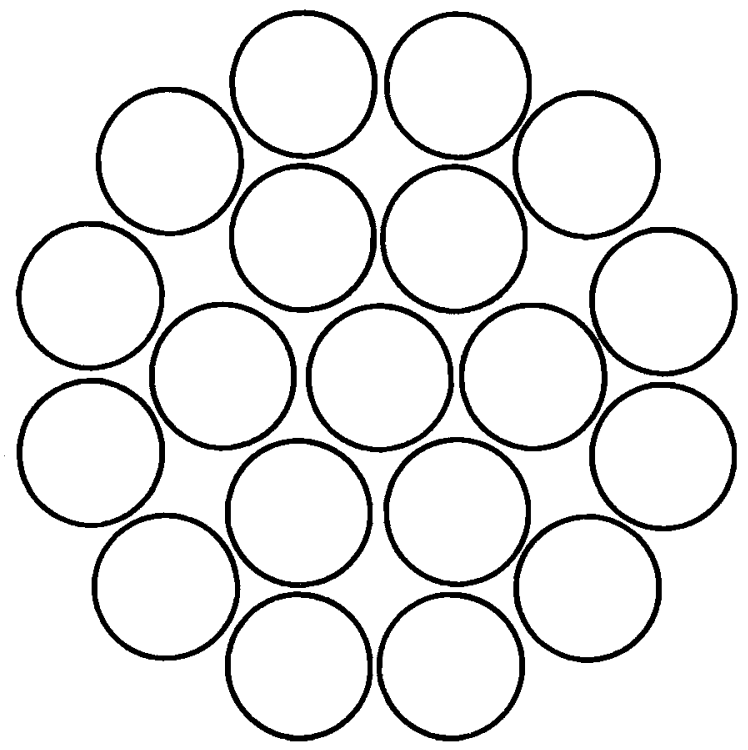

Circular Cluster (PRTR)

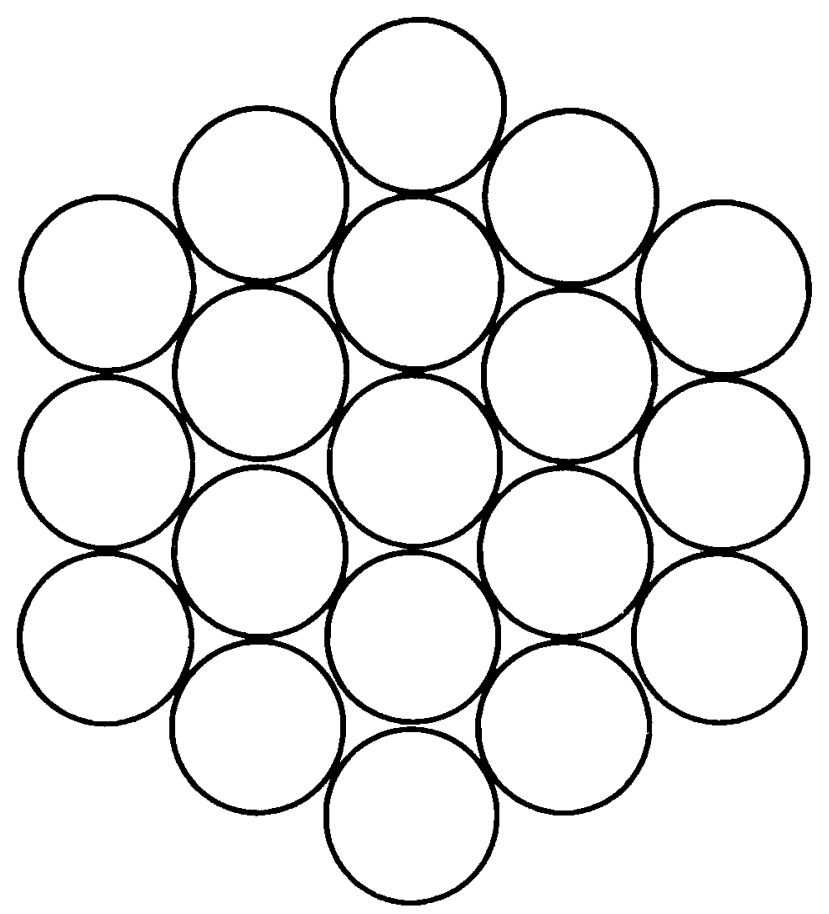

Hexagonal Cluster

Figure 3. 19-Rod Clusters 
The constant of 1.08 in Equation (3.2) is obtained by fitting the Equations (3.1) and (3.3) to the experimental data of Hellstrand.

For calculating the effective surface of a fuel element cluster with coolant between the fuel rods, the cluster is assumed to be a single fuel rod with a larger surface than the outside of the cluster. The larger surface accounts for the additional neutrons scattered into the resonance energy range by the coolant inside the cluster. The effective fuel surface ( $S_{\text {eff }}$ ) used in Equation (3.1) for calculating the resonance integral of clusters with coolant between the fuel rods is

$$
S_{\text {eff }}=S_{r b}+4 \Sigma_{M} \sum_{i} V_{M_{i}} A_{F_{i}} P_{o_{i}}
$$

where $S_{r b}$ is the rubber band surface, $\Sigma_{M}$ is the macroscopic scattering cross section of the coolant, $V_{M_{i}}$ is the volume of the ith coolant region inside the cluster, $A_{F_{i}} P_{o_{i}}$ is the probability that a neutron scattered into the resonance energy range in the ith coolant region reaches the fuel without additional scattering, and the sum is over all coolant regions inside the cluster. A coolant region is defined as the volume of coolant bounded by three or four fuel rods inside the cluster. The derivation of Equation (3.4) is given in the Appendix. 
The nonscattering probability in Equation (3.4) is expressed in terms of a geometrical parameter $A_{F_{i}}$ and a moderator noncollision probability $\mathrm{P}_{\mathrm{o}_{\dot{i}}}$. Each of these parameters is based in part on the measured resonance integral data.

The geometrical parameter $A_{F_{i}}$ accounts for the scattering of neutrons between fuel rods. For a coolant region surrounded by three equally spaced fuel rods, the equation for $A_{F_{i}}$ is

$$
A_{F_{i}}=1-\frac{6}{360} \tan ^{-1}\left[\left(\ell-2 r_{0}\right) \sqrt{3} / \ell\right] \text {, }
$$

where $l$ is the distance between fuel rod centers, $r_{0}$ is the radius of the bare fuel rods, and the inverse tangent is in degrees. For a coolant region surrounded by four equally spaced fuel rods, the equation for $A_{F_{i}}$ is

$$
\left.A_{F_{i}}=1-\frac{8}{360} \tan ^{-1}\left[\ell-2 r_{0}\right) / \ell\right]
$$

where $l$ and $r_{0}$ are the same as in Equation (3.5). The derivations of Equations (3.5) and (3.6) are given in the Appendix.

The moderator noncollision probability $\mathrm{P}_{\mathrm{o}_{i}}$ accounts for the neutrons that are scattered out of the resonance energy range before they reach the fuel. The $\mathrm{P}_{o_{i}}$ is calculated by assuming that each coolant region inside the cluster is an infinite cylinder with a volume equal to the volume of the coolant plus the 
volume of the cladding bordering the coolant region. The collision probability $\left(1-\mathrm{P}_{0}\right)$ for an infinite cylinder is given by Case, de Hoffmann, and Placzek as a function of cylinder radius and scattering cross section. In this work, the macroscopic scattering cross section of the PRTR coolant ( 97.25 percent heavy water) is taken as $0.38 \mathrm{~cm}^{-1}$. The scattering of the coolant used in the resonance integral measurements is taken as $0.35 \mathrm{~cm}^{-1}$.

The experimentally measured resonance integrals, the resonance integrals calculated from Equations (3.1), (3.2) and (3.4), and the parameters used in the calculations are listed in Table VI.

As shown in Table VI there is a reasonable agreement between the measured and the calculated resonance integrals for the hexagonal clusters over a wide range of rod pitches $(l)$ and interior coolant volumes $\left(V_{M}\right)$. $\underline{\text { Resonance Integrals for Uranium-235 and Plutonium }}$ Isotopes

The resonance integrals for the uranium-235 and the plutonium isotopes are calculated with the $\operatorname{HRG}(2,8)$ computer code using the methods of Adler, Hinman, and Nordheim (1). The calculational method uses the narrowresonance (NR) and narrow-resonance-infinite-massabsorber (NRIA) approximations to solve the integral equations for the neutron flux in the absorber. 


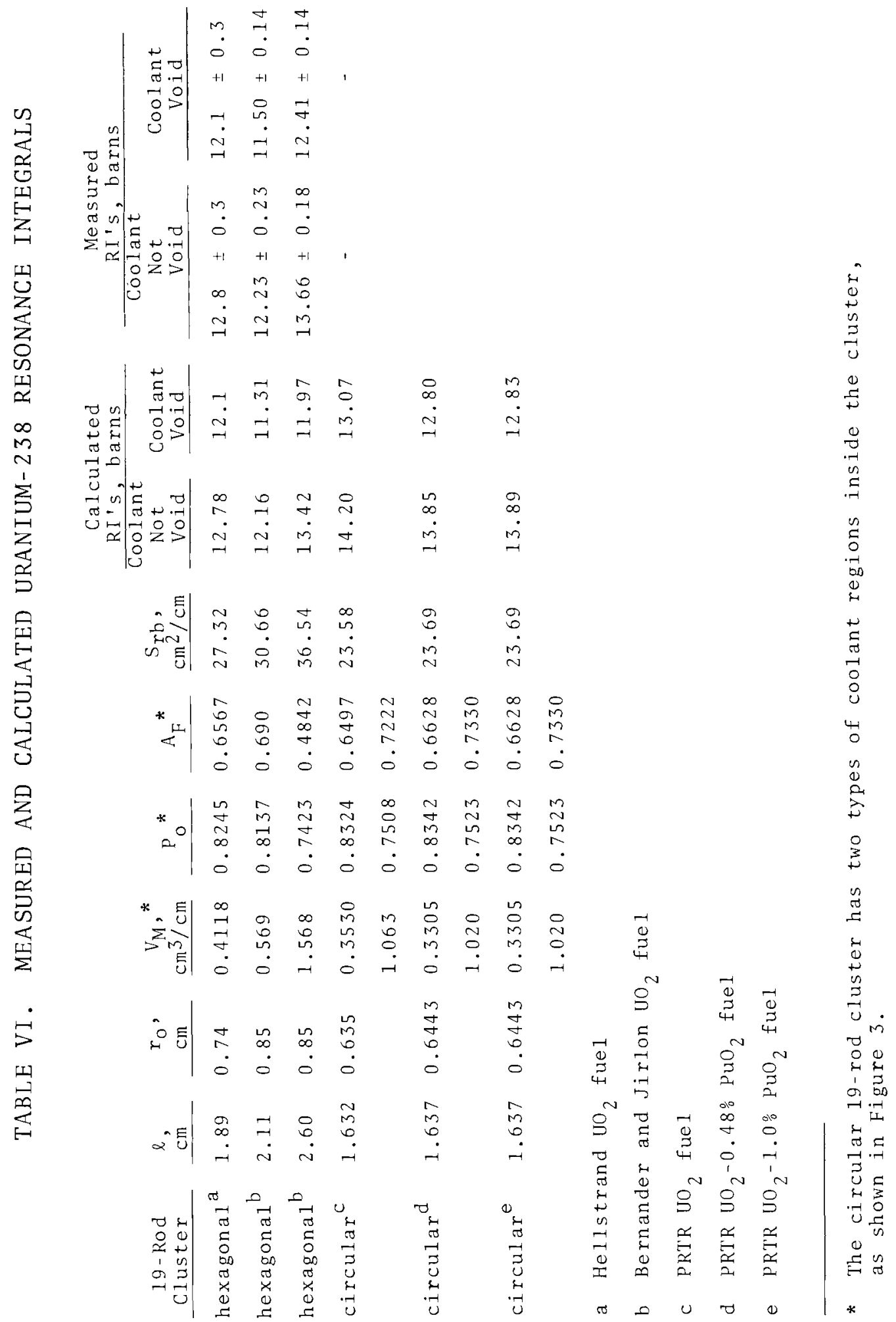


For the fuel element clusters with no coolant (air) between the fuel rods, the clusters are assumed to be a single, low density fuel rod for the resonance integral calculations. The volume of the low density fuel rod is equal to the volume of the fuel plus the volume of the cladding and void (air) inside the cluster.

For the fuel element clusters with coolant between the fuel rods, the resonance integrals are calculated for a single fuel rod and associated coolant.

A potential scattering cross section of 10.7 barns is used for the uranium and plutonium isotopes and a scattering cross section of 3.7 barns is used for the oxygen in the fuel in the resonance integral calculations.

The geometrical $\bar{l}$ (mean cord length in the fuel) parameters required to calculate the resonance integrals for the plutonium and uranium-235 isotopes are determined by finding the $\bar{l}$ parameters that will give the uranium-238 resonance integrals calculated from Equations (3.1), (3.2) and (3.4). This method of determining the $\bar{l}$ parameters is used because the $\bar{l}$ parameters cannot be simply defined for cluster type fuel elements.

The resonance integrals for uranium-238 listed in Table VI include all resonance absorption except the 
1ow energy $1 / \mathrm{v}$ absorption. The resonance integral calculation for uranium-238 in HRG considers resonance absorption up to $2.5 \mathrm{kev}$ excluding the $1 / \mathrm{v}$ absorption. Absorption in uranium-238 above $2.5 \mathrm{kev}$ is treated in HRG by cross section information on the HRG data tape. The contribution to the uranium- 238 resonance integral above $2.5 \mathrm{kev}$ is estimated to be 2.5 barns and is assumed to be independent of the coolant in the cluster. This estimate is based on contributions of 1.30 barns between $1.0 \mathrm{kev}$ and $30 \mathrm{kev}$ and 1.7 barns above $30 \mathrm{kev}$ given by Nordheim $(10)$, and a contribution of 0.5 barns between $1.0 \mathrm{kev}$ and $2.5 \mathrm{kev}$ calculated by HRG. This contribution of 2.5 barns above $2.5 \mathrm{kev}$ is subtracted from the resonance integrals 1 isted in Table VI to determine the uranium-238 resonance integrals required to determine the $\bar{\ell}$ parameters.

The calculated $\bar{\ell}$ parameters and the calculated resonance integra1s for absorption and fission in the uranium-235 and plutonium isotopes are listed in Table VII for the $\mathrm{UO}_{2}$, the $\mathrm{UO}_{2}-0.48 \% \mathrm{PuO}_{2}$ and the $\mathrm{UO}_{2}-1.0 \% \mathrm{PuO}_{2}$ fuel elements. The same $\bar{l}$ parameters are used for the $\mathrm{UO}_{2}-0.48 \% \mathrm{PuO}_{2}$ and the $\mathrm{UO}_{2}-1.0 \% \mathrm{PuO}_{2}$ fuel elements because the geometry is the same and the calculated uranium-238 resonance integrals (see Table VI) are approximately the same for both types of fue1 elements. 
ت્ધ

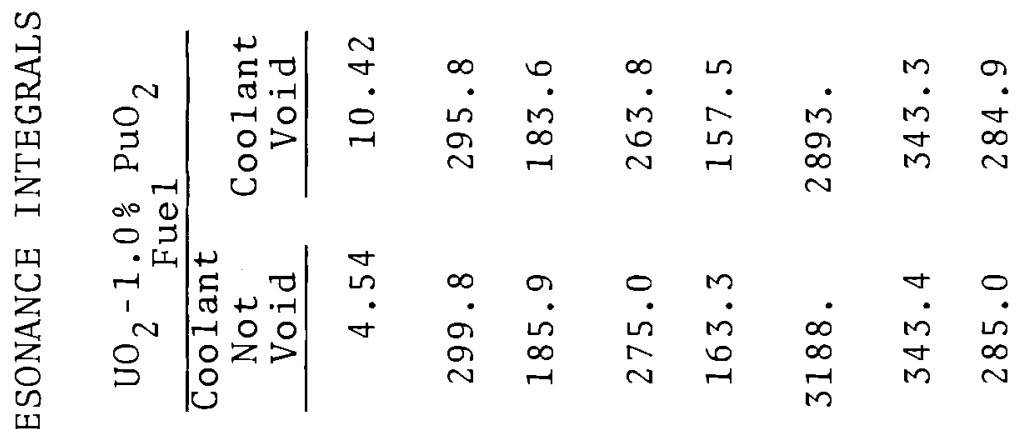

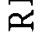

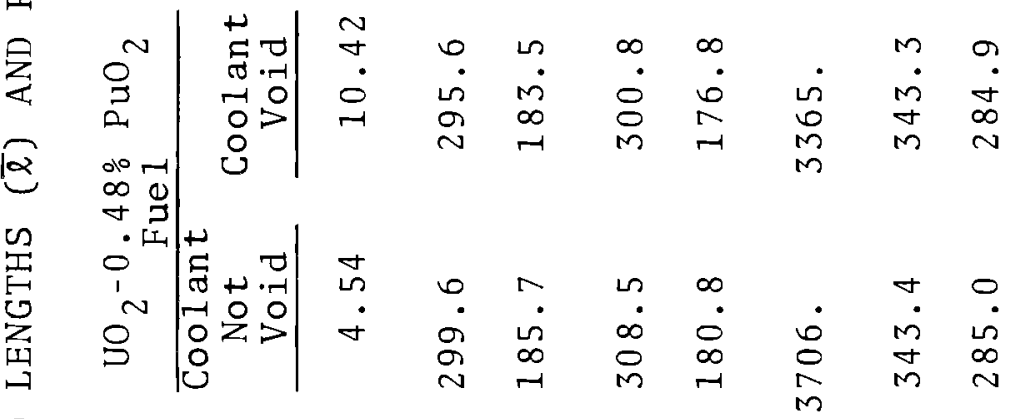

옹

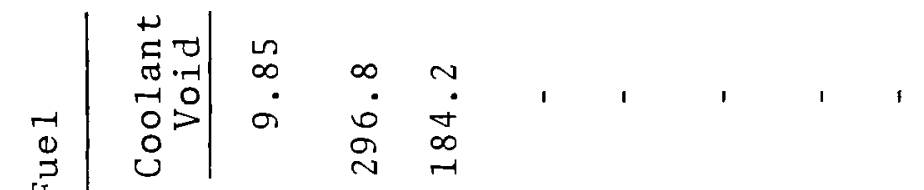

星

$\stackrel{-}{\rightrightarrows}$

岕

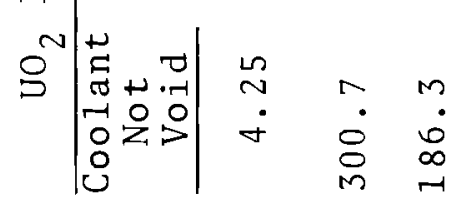

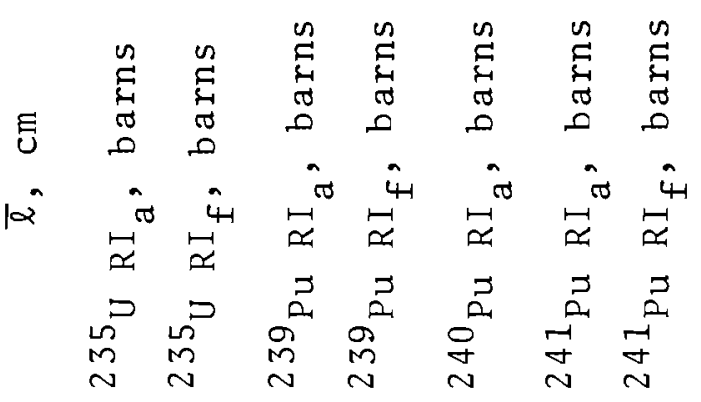


Epithermal and Fast Cross Sections

In addition to calculating the resonance integrals, the HRG code is used to calculate the average broad group epithermal and fast cross sections for each of the core regions. The HRG code computes the energy-dependent neutron flux spectrum necessary for averaging the cross sections by solving the Boltzman transport equation. The $B_{1}$ approximation is used to consider the effect of leakage on the neutron spectrum. A leakage parameter of $2.5 \times 10^{-2} \mathrm{~cm}^{-1}$ (square root of the reactor buckling) is used in all HRG calculations.

The epithermal cross sections are averaged over the neutron energies from $0.683 \mathrm{ev}$ to $1.35 \mathrm{Mev}$ and the fast cross sections are averaged over the neutron energies from $1.35 \mathrm{Mev}$ to $10 \mathrm{Mev}$ to obtain the average broad group epithermal and fast cross sections for the diffusion theory calculation. The basic cross section data is from the BNW Master Library.

The average broad group epithermal and fast cross section parameters for the three kinds of unirradiated test fuel elements are listed in Table $V$ along with the average thermal cross sections. The calculated cross section parameters for the irradiated fuel are similar to the cross section parameters for the unirradiated fue 1 isted in Table $V$. 


\section{COOLANT REACT IVITY WORTH CALCULATIONS}

The reactivity worth of the coolant is calculated by calculating the effective multiplication constant of the reactor core with and without the coolant in given process tubes using the diffusion theory code HFN (9). The HFN code uses numerical methods to solve the multiregion, one space-dimensional, multigroup diffusion equation for the lowest eigenvalue. The diffusion theory calculations of the coolant reactivity worth are performed in cylindrical geometry.

The reactor core at the time of the experimental coolant reactivity worth measurements is divided into the 17 cylindrical regions 1 isted in Table II. The fuel elements in each region are of the same enrichment with approximately the same burnup.

The neutron leakage in the axial direction is handled in HFN by an axial buckling. The axial buckling is calculated from the equation

$$
B_{z}^{2}=\left(\frac{\pi}{H+\delta_{1}+\delta_{2}}\right)^{2} \text {, }
$$

where

$$
\begin{aligned}
B_{z}^{2} & =\text { axial buckling, } \\
H & =\text { core height in } \mathrm{cm}, \\
\delta_{1} & =\text { top reflector savings in } \mathrm{cm}, \text { and } \\
\delta_{2} & =\text { bottom reflector savings in } \mathrm{cm} .
\end{aligned}
$$

The reflector savings are calculated by finding the core height with no top and bottom reflector that has 
the same multiplication constant as the core with a top and bottom reflector. The difference in the two core heights is equal to the sum of top and bottom reflector savings $\left(\delta_{1}+\delta_{2}\right)$. The reflector savings calculations are performed in slab geometry using the diffusion theory code HFN. The reactor core is assumed to consist of $\mathrm{UO}_{2}-0.48 \% \mathrm{PuO}_{2}$ fue 1 elements for the ca1culations.

The neutron leakage in the radial direction for the slab calculations is handled by a radial buckling ca1culated from the equation

$$
\mathrm{B}_{\mathrm{r}}^{2}=\left(\frac{2.405}{\mathrm{R}+\delta}\right)^{2}
$$

where

$$
\begin{aligned}
\mathrm{B}_{\mathrm{r}}^{2}= & \text { radia1 buckling, } \\
\mathrm{R}= & \text { core radius in } \mathrm{cm}, \text { and } \\
\delta= & \text { radial reflector savings in } \mathrm{cm} \text { (assumed } \\
& \text { to be } 15 \mathrm{~cm}) .
\end{aligned}
$$

The calculated sum of the top and bottom reflector savings $\left(\delta_{1}+\delta_{2}\right)$ is $30.9 \mathrm{~cm}$. Inserting this reflector savings into Equation (4.1) gives an axial buckling $\left(\mathrm{B}_{\mathrm{z}}^{2}\right)$ of $1.52 \times 10^{-4} \mathrm{~cm}^{-2}$ for the leakage correction in the diffusion theory calculation of the coolant reactivity worth.

The coolant reactivity worths calculated by HFN for the three types of unirradiated test fuel elements are listed in Table VIII. 
TABLE VIII. CALCULATED COOLANT REACTIVITY WORTHS

\begin{tabular}{|c|c|c|}
\hline Fue 1 Type & $\begin{array}{c}\text { Number } \\
\text { of Elements }\end{array}$ & $\begin{array}{r}\text { Coolant } \\
\text { Reactivity } \\
\text { Worth, mk } \\
\end{array}$ \\
\hline $\mathrm{UO}_{2}$ & 2 & -0.07 \\
\hline $\mathrm{UO}_{2}-0.48 \% \mathrm{PuO}_{2}$ & 3 & +0.14 \\
\hline $\mathrm{UO}_{2}-1.0 \% \mathrm{PuO}_{2}$ & 3 & +0.16 \\
\hline
\end{tabular}


V. MODERATOR LEVEL COEFFICIENT CALCULATIONS

As stated in Chapter II, the reactivity worth of the coolant was measured in terms of a change in the moderator level. To compare the measured coolant reactivity worth to the calculated coolant reactivity worth in $\mathrm{mk}$, the moderator level coefficient (mk per $\mathrm{cm}$ of moderator level) must be calculated. The moderator level coefficient is calculated by performing diffusion theory calculations in slab geometry. The multiplication constant is calculated at two moderator levels, and the moderator level coefficient is equal to the difference in the two multiplication constants divided by the difference in the moderator levels. The bottom reflector region for the slab calculations consists of the $\mathrm{D}_{2} \mathrm{O}$ moderator, the process tubes, the shroud tubes, and the primary coolant. The top reflector region is the same with the addition of the stainless steel fuel hanger rods.

The radial buckling for the slab calculations is calculated from Equation (4.2). The calculations are performed for single region cores of $\mathrm{UO}_{2}-0.48 \% \mathrm{PuO}_{2}$ and $\mathrm{UO}_{2}-1.0 \% \mathrm{PuO}_{2}$ fuel element clusters.

Moderator level coefficients of $0.195 \mathrm{mk} / \mathrm{cm}$ and $0.213 \mathrm{mk} / \mathrm{cm}$ are calculated at a moderator level of $250.50 \mathrm{~cm}$ for the $\mathrm{UO}_{2}-0.48 \% \mathrm{PuO}_{2}$ and $\mathrm{UO}_{2}-1.0 \% \mathrm{PuO}_{2} \mathrm{sin}-$ gle region reactor cores. These calculated moderator 
level coefficients agree well with a moderator level coefficient of $0.21 \pm 0.01 \mathrm{mk} / \mathrm{cm}$ that was measured at the PRTR in March, 1962, by V. W. Gustafson (4). The moderator level coefficient was measured at a moderator level of $264 \mathrm{~cm}$ by making period measurements. 
VI. COMPARISON OF MEASURED AND CALCULATED

\section{COOLANT REACTIVITY WORTHS}

The measured changes in the critical moderator level resulting from removing the coolant from the unirradiated test fuel elements listed in Table I are converted to coolant reactivity worths using the average calculated moderator level coefficient of $0.204 \mathrm{mk} / \mathrm{cm}$.

These measured coolant reactivity worths converted to $\mathrm{mk}$ are 1 isted in Table IX along with the calculated coolant reactivity worths from Table VIII for the $\mathrm{UO}_{2}$, the $\mathrm{UO}_{2}-0.48 \% \mathrm{PuO}_{2}$, and the $\mathrm{UO}_{2}-1.0 \% \mathrm{PuO}_{2}$ unirradiated test fuel elements.

As shown in $\mathrm{Tab} l \mathrm{e} I \mathrm{X}$, the calculated reactivity worth of the coolant agrees with the measured reactivity worth of the coolant for the $\mathrm{UO}_{2}$ and the $\mathrm{UO}_{2}-0.48 \% \mathrm{PuO}_{2}$ fuel elements. For the $\mathrm{UO}_{2}-1.0 \% \mathrm{PuO}_{2}$ fuel elements, the calculational method overestimates the coolant reactivity worth.

TABLE IX. MEASURED AND CALCULATED COOLANT REACT IVITY WORTHS

Number Measured Calculated of Fue 1 Reactivity Reactivity

\begin{tabular}{|c|c|c|c|}
\hline Fue 1 Type & E1ements & Worth, $\mathrm{mk}$ & Worth, mk \\
\hline $\mathrm{UO}_{2}$ & 2 & $-0.077 \pm 0.008$ & -0.07 \\
\hline $\mathrm{UO}_{2}-0.48 \% \mathrm{PuO}_{2}$ & 3 & $+0.100 \pm 0.012$ & +0.14 \\
\hline $\mathrm{UO}_{2}-1.0 \% \mathrm{PuO}_{2}$ & 3 & $+0.018 \pm 0.010$ & +0.16 \\
\hline
\end{tabular}


To determine possible reasons for this overestimation, the contribution to the coolant reactivity worth from each cross section parameter is estimated by calculating the change in the multiplication constant which results from a change in each parameter. The calculated contributions to the coolant reactivity worth due to changes in each cross section are listed in Table $\mathrm{X}$ for the $\mathrm{UO}_{2}-0.48 \% \mathrm{PuO}_{2}$ and the $\mathrm{UO}_{2}-1.0 \% \mathrm{PuO}_{2}$ fuel elements.

As shown in $\mathrm{Tab} 1 \mathrm{e} X$, the coolant reactivity worth is primarily determined by changes in the epithermal capture, thermal capture, thermal fission, and epithermal scattering cross sections. Since the contribution to the coolant reactivity worth from changes in each of these cross sections is larger in absolute magnitude than the net coolant worth 1 isted in Table IX, sma11 errors in these cross sections will produce 1 arge errors in the calculated coolant reactivity worth.

For example, the change in the epithermal capture cross section depends primarily on the change in the uranium-238 resonance integra1. As shown in Table VI, the uranium-238 resonance integra1 changes by 1.06 barns when the coolant is removed from the $\mathrm{UO}_{2}-1.0 \% \mathrm{PuO}_{2}$ fue 1 cluster. If the possible error in the uranium-238 resonance integral with coolant relative to the resonance integral without coolant is assumed to be 0.3 barns 
TABLE $X$. CALCULATED CONTRIBUTIONS TO THE COOLANT REACTIVITY WORTH FROM CHANGES IN EACH CROSS SECTION

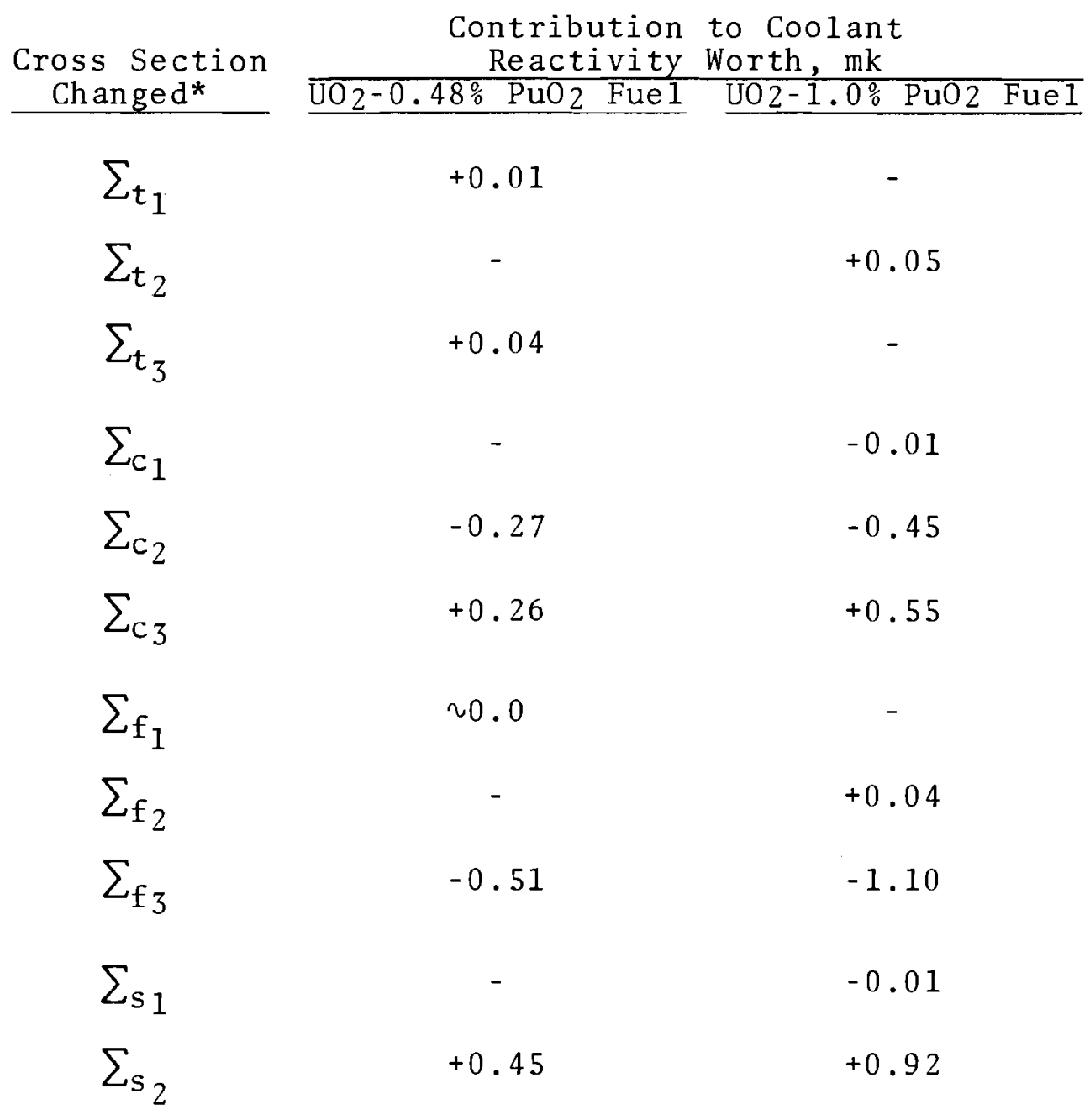

* 1 fast neutron energy group ( $1.35 \mathrm{Mev}$ to $10 \mathrm{Mev}$ )

2 epithermal neutron energy group $(0.683 \mathrm{ev}$ to $1.35 \mathrm{Mev}$ )

3 thermal neutron energy group ( 0 to $0.683 \mathrm{ev}$ )

$\sum_{t_{i}}$ transport cross section for energy group $i$

$\sum_{c_{i}}$ capture cross section for energy group $i$

$\sum_{f_{i}}$ fission cross section for energy group $i$

$\sum_{s_{i}}$ scattering cross section for energy group i 
(a reasonable assumption considering the possible experimental errors listed in Table VI), the $-0.45 \mathrm{mk}$ epithermal capture contribution to the coolant reactivity worth 1 isted in Table $\mathrm{X}$ for the $\mathrm{UO}_{2}-1.0 \% \mathrm{PuO}_{2}$ fue 1 could be in error by $(0.3 / 1.06)(0.45)=0.13 \mathrm{mk}$. This would give a calculated coolant reactivity worth of $0.16 \pm 0.13 \mathrm{mk}$ relative to the measured coolant reactivity worth of $0.018 \pm 0.010 \mathrm{mk}$ for the $\mathrm{UO}_{2}-1.0 \% \mathrm{PuO}_{2}$ fue1. The error for the $\mathrm{UO}_{2}-0.48 \% \mathrm{PuO}_{2}$ fuel elements would be $0.076 \mathrm{mk}$ which would give a calculated coolant worth of $0.14 \pm 0.076 \mathrm{mk}$.

Similar possible errors may exist in the epithermal scattering, thermal capture and thermal fission cross sections. 
VII. SUMMARY AND CONCLUSIONS

In this work, a method is developed for calculating the reactivity worth of the coolant of the PRTR. The coolant reactivity worth is determined by calculating the effective multiplication constant of the reactor core with and without the coolant in given process tubes. The calculational method includes a method for calculating the resonance integrals for PRTR circular 19-rod cluster fuel elements based on experimental resonance integral data for single $\mathrm{UO}_{2}$ fuel rods and hexagonal 19 -rod clusters of $\mathrm{UO}_{2}$ fue 1 rods.

The calculational method is compared with previously measured coolant reactivity worths. The reactivity worth of the coolant for the two $\mathrm{UO}_{2}$ fuel elements is calculated to be $-0.071 \mathrm{mk}$ which agrees with the measured worth of $-0.077 \mathrm{mk}$. The coolant reactivity worth for the three $\mathrm{UO}_{2}-0.48 \% \mathrm{PuO}_{2}$ fue 1 elements is calculated to be $0.14 \mathrm{mk}$ which is in reasonable agreement with the measured worth of $0.10 \mathrm{mk}$. For the three $\mathrm{UO}_{2}-1.0 \% \mathrm{PuO}_{2}$ fuel elements, the reactivity worth of the coolant is calculated to be $0.16 \mathrm{mk}$, which is not in agreement with the measured worth of $0.018 \mathrm{mk}$. The coolant worth for the three $\mathrm{UO}_{2}-1.0 \% \mathrm{PuO}_{2}$ fuel elements was measured twice, and thus the calculated reactivity worth is most likely in error. 
The possible error in the calculated coolant reactivity worth is evaluated by calculating the reactivity change produced by the change in each individual multigroup cross section. For the three $\mathrm{UO}_{2}-1.0 \% \mathrm{PuO}_{2}$ fuel elements, the changes in the cellaveraged epithermal capture, thermal capture, thermal fission, and epithermal scattering multigroup cross sections produce calculated reactivity changes of -0.45 , $+0.55,-1.10$, and $+0.92 \mathrm{mk}$ respectively which are each greater in absolute magnitude than the net reactivity change of $+0.16 \mathrm{mk}$.

Based on the experimental errors in the uranium-238 resonance integrals, a possible error of 0.3 barns (approximately two percent of the resonance integral) is assumed for the uranium-238 resonance integral with coolant relative to the resonance integral without coolant. This possible error in the uranium-238 resonance integral gives a calculated coolant reactivity worth of $0.16 \pm 0.13 \mathrm{mk}$ relative to the measured worth of $0.018 \pm 0.010 \mathrm{mk}$ for the three $\mathrm{UO}_{2}-1.0 \% \mathrm{PuO}_{2}$ fuel elements, and a calculated coolant worth of 0.14 $\pm 0.076 \mathrm{mk}$ relative to the measured worth of 0.10 $\pm 0.012 \mathrm{mk}$ for the three $\mathrm{UO}_{2}-0.48 \% \mathrm{PuO}_{2}$ fuel elements. Possible errors in the calculated coolant worth may also exist due to errors in the calculated epithermal scattering, thermal capture and thermal fission multigroup cross sections. 
In conclusion, the calculational method developed in this work will calculate the reactivity worth of the coolant of the PRTR within the accuracy of the cross section data. 


\section{BI BL IOGRAPHY}

1. Adler, F. T., G. W. Hinman and L. W. Nordheim. The quantitative evaluation of resonance integrals. In: Proceedings of the Second United Nations International Conference on the Peaceful Uses of Atomic Energy, Geneva, 1958. Vol. 16. p. 155-171.

2. Carter, J. L. Computer Code - HRG. In: Technical activities quarterly report, July, August, September, 1966. p. 66-68. (U.S. Atomic Energy Commission. BNWL-340)

3. Case, K. M., F. de Hoffmann and G. Placzek. Introduction to the theory of neutron diffusion. Washington, D.C., U.S. Government Printing Office, 1953. $174 \mathrm{p}$.

4. Gustafson, V. W. PRTR test number 27, moderator level coefficient tests. Richland, Washington, Hanford Laboratory, 1962. (Unpublished)

5. Hellstrand, E. Measurements of the effective resonance integral in uranium metal and oxide in different geometries. Journal of Applied Physics $28: 1493-1502$. 1957.

6. He11strand, E. The resonance integral for uranium metal and oxide. Nuclear Science and Engineering $9: 435-436$. 1961 .

7. Honeck, H. C. THERMOS, a the rmalization transport theory code for reactor lattice calculations. 1961. 77 p. (U.S. Atomic Energy Commission. BNL-5826)

8. Joanou, G. D. and J. S. Dudek. GAM-I: A consistent $\mathrm{P}_{1}$ multigroup code for the calculation of fast neutron spectra and multigroup constants. 1961. 137 p. (U.S. Atomic Energy Commission. GA-1850)

9. Lilley, J. R. Computer code HFN-multigroup neutron diffusion theory in one space dimension. 1961.

54 p. (U.S. Atomic Energy Commission. HW-71545)

10. Nordheim, L. W. A new calculation of resonance integrals. Nuclear Science and Engineering $12: 457-463$. 1962 . 
11. Pershagen, B. Heavy water lattice calculations in Sweden. In: Heavy water lattices: Second pane1 report, 1963. Vienna, International Atomic Energy Agency, 1963. p. 257-303.

12. Shuddle, R. H. and J. Dyer. TEMPEST, A neutron thermalization code. Los Angeles, North American Aviation Corporation, 1960. (Unpublished)

13. Smith, R. I. Burnup calculations. Richland, Washington, Hanford Laboratory, 1963. (Unpub1ished)

14. Smith, R. I. PRTR test number 63 , reactivity worth of coolant removal from fuel channels. Richland, Washington, Hanford Laboratory, 1964 . (Unpub1 ished)

15. Stephenson, R. Introduction to nuclear engineering. New York, McGraw-Hi11, 1958. 491 p.

16. Stewart, K. B. BNW master 1ibrary. 1965. $200 \mathrm{p}$. (U.S. Atomic Energy Commission. BNWL-CC-325)

17. Wittenbrock, N. G., P. C. Walkup and J. K. Anderson. Plutonium recycle test reactor, final safeguards analysis. 1959. 304 p. (U.S. Atomic Energy Commission. HW-61236)

18. Worden, J. R., W. L. Purcell and R. C. Liikala. Modifications to the computer code THERMOS, and comparative studies on scattering kernals. In: Physics research quarterly report, July, August, September, 1965. p. 5-15. (U.S. Atomic Energy Commission. BNWL-193) 
A $P$ P $P$ E $N$ D 
APPENDIX

DERIVATION OF THE EQUATIONS FOR CONVERTING

FUEL ELEMENT CLUSTERS TO SINGLE FUEL RODS

FOR CALCULATING THE URANIUM-238

RESONANCE INTEGRALS

He11strand has shown that the uranium-238 resonance integral (RI) in barns for a fuel rod can be expressed by the following equation

$$
R I=4.15+26.6 \sqrt{S / M}
$$

where $S$ is the surface of the fuel rod per unit length in $\mathrm{cm}^{2} / \mathrm{cm}$ and $\mathrm{M}$ is the mass of the fuel per unit length in $\mathrm{grams} / \mathrm{cm}$.

In this appendix, equations are derived to convert a cluster type fuel element to a single fuel rod such that Equation (A.1) can be used to calculate the uranium-238 resonance integral of clusters.

For a fuel surface in an infinite scattering media where absorption can be neglected, the neutron current $(J)$ into the fuel surface is

$$
\mathrm{J}=\phi / 4 \text {, }
$$

where $\phi$ is the neutron flux in the scattering media. A derivation of Equation (A.2) is given in Stephenson (15) on pages 138 and 139 . 
If $\phi_{1} \Sigma_{s} d V$ is the number of scattering collisions per unit time in volume element $\mathrm{dV}$ that scatter neutrons into resonance energies, the number of resonance energy neutron per second $\left(I_{1}\right)$ that enter a fuel element cluster or a single fuel rod from scattering col1ision in the moderator outside the fuel cluster or fue 1 rod is

$$
I_{1}=\phi_{1} S_{F} L / 4
$$

where $S_{F}$ is the outside surface of the fuel per unit length and $L$ is the length of the fuel. For a cluster, $S_{F}$ is assumed to be $S_{r b}$ (the surface that would be formed if a rubber band were stretched around the cluster).

For a moderator region $i$ inside a fuel element cluster (the coolant between the fuel rods), the number of scattering collisions that scatter neutrons into resonance energies is $\phi_{1} \Sigma_{S} V_{M_{i}}$ where $V_{M_{i}}$ is the volume of the moderator region $i$, per unit length of fuel and $\Sigma_{S}$ is the macroscopic scattering cross section of the moderator.

The number of resonance energy neutrons per second $\left(\mathrm{I}_{2}\right)$ that enter the fuel rods from scattering collisions in the moderator (coolant) inside a cluster is

$$
I_{2}=L \sum_{i} \phi_{1} \Sigma S V_{M_{i}} A_{F_{i}} P_{o_{i}}
$$


where $\phi_{1} \Sigma_{S} V_{M_{i}}$ and $L$ are defined above, $A_{F_{i}}$ is a geometrical parameter that accounts for the scattering of neutrons between the fue 1 rods, $\mathrm{P}_{\mathrm{o}_{i}}$ is a moderator noncollision probability, and the sum is over all moderator regions inside the cluster.

The total number of resonance energy neutrons per second $\left(\mathrm{I}_{\mathrm{T}}\right)$ that enter the fuel from all scattering collisions is the sum of Equations (A.3) and (A.4) which is

$$
I_{T}=\frac{\phi_{1} L}{4}\left(S_{r b}+4 \Sigma \sum_{S} \sum_{i} V_{M_{i}} A_{F_{i}} P_{o_{i}}\right),
$$

where the neutron $f 1 u x \phi_{1}$ in the moderator outside the cluster is assumed to be equal to the neutron flux $\phi_{1}$ in the moderator (coolant) inside the cluster.

If a cluster is assumed to have an effective fuel surface of

$$
S_{\text {eff }}=S_{r b}+4 \Sigma_{S} \sum_{i} V_{M_{i}} A_{F_{i}} P_{i}
$$

the number of resonance energy neutrons per second that enter the cluster is in the same form as Equation (A.3) for a single fuel rod.

The effective fuel surface given by Equation (A.6) is used in Equation (A.1) for calculating the uranium-238 resonance integral for a fuel element cluster with coo1ant between the fue 1 rods. 
The geometrical parameter $A_{F_{i}}$ is based in part on the experimental measurements. For a coolant region surrounded by three equally spaced fuel rods, $A_{F_{i}}$ is calculated from the equation

$$
\mathrm{A}_{\mathrm{F}_{i}}=1-3 \alpha / 360
$$

where $\alpha$ is the angle in degrees shown in Figure 4. The angle $\alpha$ is given by the equation

$$
\alpha=2 \tan ^{-1}\left(\ell-2 \mathrm{r}_{0}\right) \sqrt{3} / \ell
$$

where $r_{0}$ is the radius of the bare fuel rod and $\ell$ is the distance between the fue 1 rod centers.

For a coolant region surrounded by four equally spaced fuel rods, $A_{F_{i}}$ is calculated from the equation

$$
A_{F_{i}}=1-4 \beta / 360
$$

where $\beta$ is the angle in degrees shown in Figure 4. The angle $\beta$ is given by the equation

$$
\beta=2 \tan ^{-1}\left(\ell-2 r_{0}\right) / \ell
$$

where $r_{0}$ and $\ell$ are the same as for Equation (A.8). 


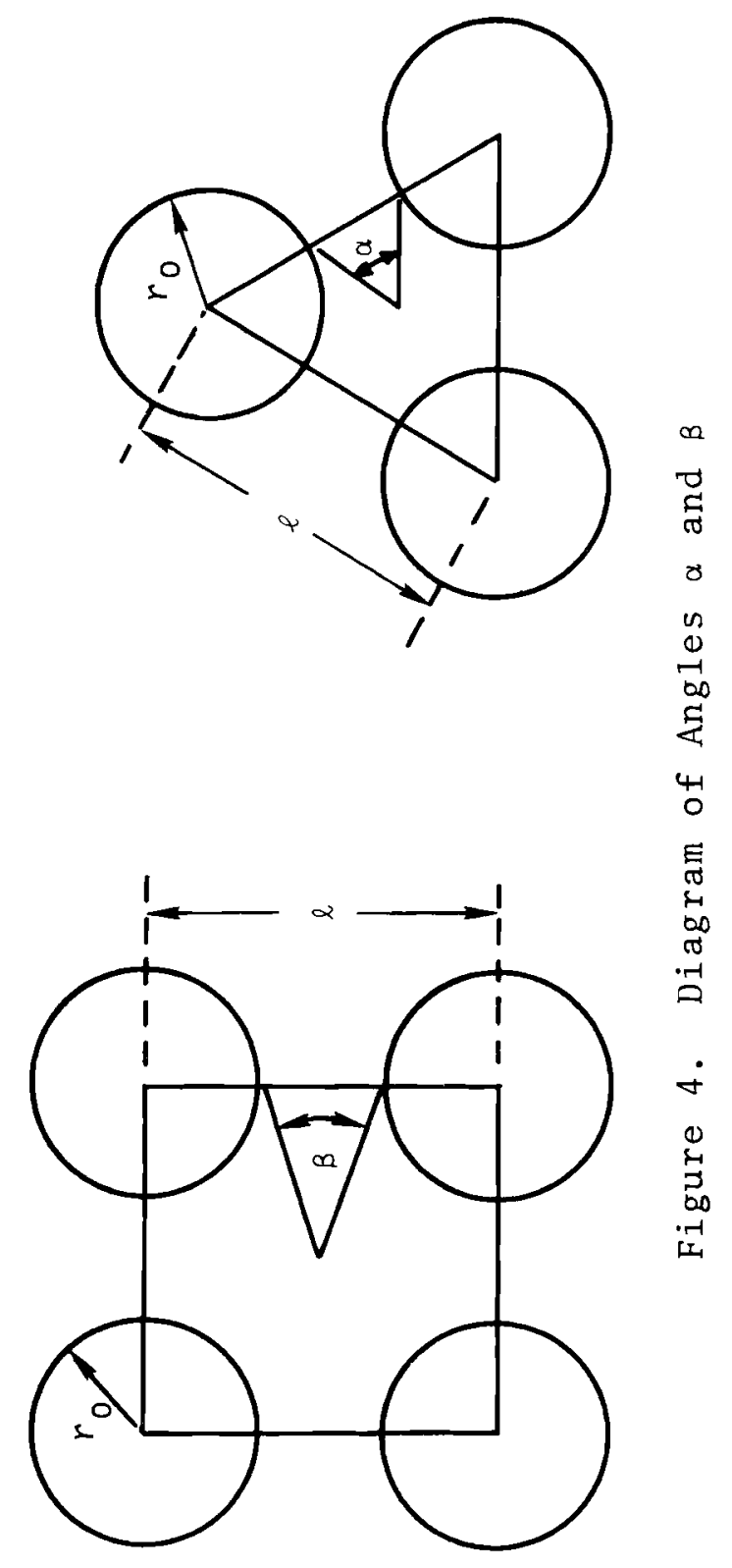




\section{ACKNOWLEDGEMENTS}

The author gratefully acknowledges the assistance of R. I. Smith of Battelle-Northwest for obtaining the experimental data, Dr. J. L. Carter, R. C. Liikala, W. L. Purcel1, and J. R. Worden of Battelle-Northwest for providing the operational computer codes and cross section data tapes, and Dr. L. C. Schmid of BattelleNorthwest and Dr. J. C. Ringle of Oregon State University for their valuable comments and suggestions on the manuscript. 
DISTRIBUTION

No. of

Copies

OFFSITE

1

2

3

2

ONSITE

1

1

1

2

52

AEC Chicago Patent Group

G. H. Lee

AEC Division of Technical Information Extension

AEC Division of Reactor Development and Technology

Reactor Physics Br., W. Hannum

Reactor Physics Br., J. W. Lewe1len

Water Projects Br., J. Kruth

Atomic Energy of Canada Limited

M. Duret

C. Millar

AEC Chicago Patent Group

R. K. Sharp

AEC RDT Site Representative

W. E. Fry

AEC Richland Operations Office

C. L. Robinson

RDT Assistant Director for Pacific Northwest Programs

Batte11e-Northwest

G. J. Busselman

J. L. Carter

N. E. Carter

F. G. Dawson

J. R. Fishbaugher

M. D. Freshley 
Battelle-Northwest (contd)

S. Goldsmith

G. E. Hans on

C. E. Heeb

R. H. Holeman

U. P. Jenquin

J. W. Kutcher

R. C. Liikala

J. L. Maryott

R. P. Matsen

W. W. Porath

D. L. Prezbindowski

R. H. Purcell

W. L. Purcel1

W. D. Richmond

L. C. Schmid

R. I. Smith

K. B. Stewart

D. H. Thomsen

V. O. Uotinen

L. D. Williams

W. C. Wolkenhauer

K. L. Young

Technical Information

Technical Publications 